\title{
The Effect of Servant Leadership on Work Engagement and Affective Commitment Mediated by Job Satisfaction on Education Staff at Private Universities in West Jakarta
}

\author{
Deasy Aseanty ${ }^{1}$, Andreas ${ }^{2}$, Ismi Lutfiyani ${ }^{3}$ \\ \{deasy.aseanty@trisakti.ac.id ${ }^{1}$, andreaswg@trisakti.ac.id ${ }^{2}$, Ismilutfiyani27@gmail.com ${ }^{3}$ \} \\ Faculty of Economic and Business, Universitas Trisakti, Inonesia
}

\begin{abstract}
This study aims to analyze the effect of servant leadership on work engagement and affective commitment mediated by job satisfaction on education staffs at private universities in West Jakarta. In this research, the sample was collected by purposive sampling, namely the employees. They are 152 employees as sample of this research. Hypothesis testing with descriptive statistics using SEM, amos software. The results of this study shows that it has a positive effect.The results of this study support a series of hypotheses where Servant leadership has a positive effect on work engagement and affective commitment, and supports the hypothesis that Servant leadership has a positive effect on work engagement and affective commitment mediated by job satisfaction. The implication of this research is that management is expected to be able to maintain employee morale, make employees enjoy working time, increase employee engagement and commitment and employees feel that the company is an important part of themselves.
\end{abstract}

Keywords: Servant Leadership; Work Engagement; Affective Commitment; Job Satisfaction

\section{Introduction}

\subsection{Background}

Entering 2020, the whole world was facing the situation of the COVID19 pandemic that has occurred in many countries in the world until present. This pandemic has already caused many changes in every aspects. In addition to the infected people; this pandemic also made great number of mortality. Aside the major impact to the health sector, this pandemic also made a great impact in other fields, such as economic sector. Every government of each country has already issued new rules or policies regarding to this crisis. In Indonesia, the government has already implemented large-scale social restrictions (PSBB) and asked workers to be able to work from home, as well as students to study from home. This government policy is certainly a focus of attention for company management, where they need to reorganize their company management due to new policies. 
Implementing government regulations where employees must work from home is not something easy to manage. Therefore, companies need to rearrange many things for tasks can still be carried out with technology and its capability to help workers get their work done in long-distance. For managers, the application of technology can help them especially in monitoring the work of their employees. Leaders need to organize a new leadership strategy that adapts to the newly pattern that has just occured in their company. As we can imagine, many employees are still having a hard time adjusting to this pandemic situation with the mechanism of working from home. So the managers need to continue to serve them well, so that the problems of the workers can be eliminated.

Servant leadership will keep employees comfortable while working even with the new order patterns that just occured. On the other hand, the company certainly hopes that this pandemic situation can make the company survive, so that company activities can continue to achieve their goals. For the education sector, especially universities, the human resource aspect is a very important element in achieving their goals. One of them is employees of Educational Sectors. They are employees with great influence for the sustainability of the university. There are so many positive impacts that companies can receive if their educational staff can work well.

The performance of educational personnel is influenced by how they can interpret their work and complete their job well, as well as their commitment to keep working at the college. The situation is influenced by how their leader can serve them well, so that they are comfortable, and they will be satisfied, their satisfaction is the beginning of an increase in work engagement and affective commitment. Research has shown the important role that Servant leadership plays in improving how employees feel about their jobs [1]. Servant leadership encourages morale among subordinates(Schaufeli and Bakker 2004), because they recognize their unique skills and competencies (Van Dierendonck and Nuijten 2011). Thus, servant leadership creates a kind of psychological safety net among employees(Schaubroeck et al., 2011), which will ultimately encourage their involvement(Greenleaf 2002). Study of[5],(Coetzer et al., 2017),[7],[8] and (Ling et al., 2017) found that Servant leadership has a positive impact on work engagement.

Regarding the relationship between leadership and commitment, previous research has shown that leadership is very important to increase organizational commitment(Dick 2011; Jackson et al., 2013). (Stone et al., 2004)found that Servant leadership has the same aspects, namely trust, vision, respect, integrity and delegation. This shows that servant leadership can play a role in increasing organizational commitment among followers.[5], in a qualitative study found that servant leadership has an impact on employee organizational commitment. Based on this, it appears that employees, who perceive their leaders as more servant and less selfish, are more likely to feel emotionally attached and dedicated to their organization.

Employees show higher levels of satisfaction when they have a leader whose primary concern is the well-being of followers[13], [8], (Neubert et al., 2016) and [15] find that Servant leadership plays an important role in increasing employee job satisfaction. Moreover, it can be said that satisfied employees show a higher level of employee engagement(Blizzard 2004; Saks 2006). In the same line of inquiry, job satisfaction is seen as an antecedent to organizational commitment (Meyer et al., 2002). This argument has received support from previous research from[19] and [8], who found that satisfied employees were more likely to show higher levels of organizational commitment.

This study will examine the impact of Servant leadership on work engagement and Affective commitment mediated by job staisfaction on education staff employees of private universities in West Jakarta who are ranked in the top 5 (five) best private universities in 
Jakarta according to LLDIKTI in 2020. The education staff are one of the most vital supporting aspects in helping universities to carry out all online activities. Several previous studies that have been conducted before the current pandemic. The focus of this research is after the pandemic occurs. Where during the pandemic everyone switches to online, working from home, everyone must be able to use technology.

This research is related to green society considering that in a company between leaders and employees it is necessary to create a working relationship that is not only harmonious, but also be able to understand each other, so that in the end the goals can be achieved easily. Related to this situation, how managers can lead their employees with this new era of working, is a new way that we need to strive for so that both parties can carry out this as comfortable as possible, because relationships between individuals must established properly, one of them is the implementation of Servant leadership from the leadership to the employees.

\subsection{Formulation of the Problem}

a. Is there a positive effect between servant leadership to work engagement of private universities employees in West Jakarta?

b. Is there a positive effect between servant leadership to affective commitment of private universities employees in West Jakarta?

c. Is there a positive effect between servant leadership to work engagement mediated by job satisfaction of private universities employees in West Jakarta?

d. Is there a positive effect between servant leadership to affective commitment mediated by job satisfaction of private universities emplyees in West Jakarta?

\subsection{Research Purposes}

a. To analyze Servant leadership of private universities in West Jakarta.

b. To analyze work engagement on education staff of private universities in West Jakarta

c. To analyze the affective commitment on education staffs of private universities in West Jakarta

d. To analyze job satisfaction on education staffs of private universities education in West Jakarta

e. To analyze the positive effect of Servant leadership to work engagement on education staffs of private universities in West Jakarta

f. To analyze the positive effect of Servant leadership to Affective commitment on education staffs of private universities in West Jakarta

g. To analyze the positive effect of Servant leadership to work engagement mediated by job satisfaction on education staffs of private universities in West Jakarta.

h. To analyze the positive effect of Servant leadership to Affective commitment mediated by Job satisfaction on education staffs of private universities in West Jakarta.

\subsection{Research Limitation}

a. This study only examines education staffs of private universities in West Jakarta

b. This study only examines the effect of Servant leadership on work engagement and affective commitment mediated by job satisfaction. 


\subsection{Benefits of Research}

a. Management in higher education field:

Fostering the good relationship with the internal staffs, due to the importance of their existing

b. Developing the related knowledge:

Enhancing the increasing knowledge about Human Resource Management, especially about the importance of Servant Leadership, Job Satisfaction, Work Engagement, and Affective Commitment.

c. As a reference for future researchers

In addition to contribute the researchers who will develop the next research.

\section{Literature Review}

\subsection{Work Engagement}

Job engagement is a positive work-related state of mind in which employees see themselves as capable of handling the demands of their job well (Schaufeli 2011). Work engagement was initially characterized by passion, dedication, and absorption, but various researchers consider passion and dedication to be the "core components" of work engagement, and more absorption as a consequence.(Schaufeli and Bakker 2004; Schaufeli 2013; Taris et al., 2017). Furthermore,[23]stated that work engagement requires good working conditions in the form of work resources, as well as supporting personal resources. In addition, job involvement affects job satisfaction, commitment to the organization(Hayward et al. 2015; Geldenhuys et al., 2014; Parent and Lovelace 2015; VOKIC 2015).

\subsection{Affective Commitment}

Affective commitment is an emotional bond in employees to include themselves with the company where they work [28]. according to Cut Zurnali (2010) Affective commitment is the feeling of employees to stay in an organization because they really want to and build social relationships and appreciate the value of relationships with the organization because they have become members. When employees have low affective commitment, there is no incentive to develop employee relationships with the organization(Fazio \& Yurova, 2016).

\subsection{Servant Leadership}

Servant leadership is a boss who puts the needs of his subordinates first, starting from the feeling in someone who wants to put his subordinates first(Spears, 2002). according to (Van Dierendonck et al., 2014),Servant leadership is characterized by humility, escort of members, personal acceptance of each member, empowerment, and giving direction to members. Servant leadership is leadership that begins with sincere feelings that arise from the heart to serve, prioritize the needs of its members, solve problems that exist in the organization to help members achieve common goals. 


\subsection{Job Satisfaction}

Job satisfaction considered to be the most studied attitude in the field of organizational behavior (Alvinius et al., 2017). Then(Akehurst et al., 2009)argues that job satisfaction is a feeling of pleasure in employees about their work. Job satisfaction is very important because when employees feel satisfied with their work, the employee will show positive work behaviors such as low absenteeism and higher performance.[32]. In addition, employee job satisfaction can occur by building a team, providing rewards, training, and effective communication(Cook, 2008).

\subsection{Conceptual Framework}

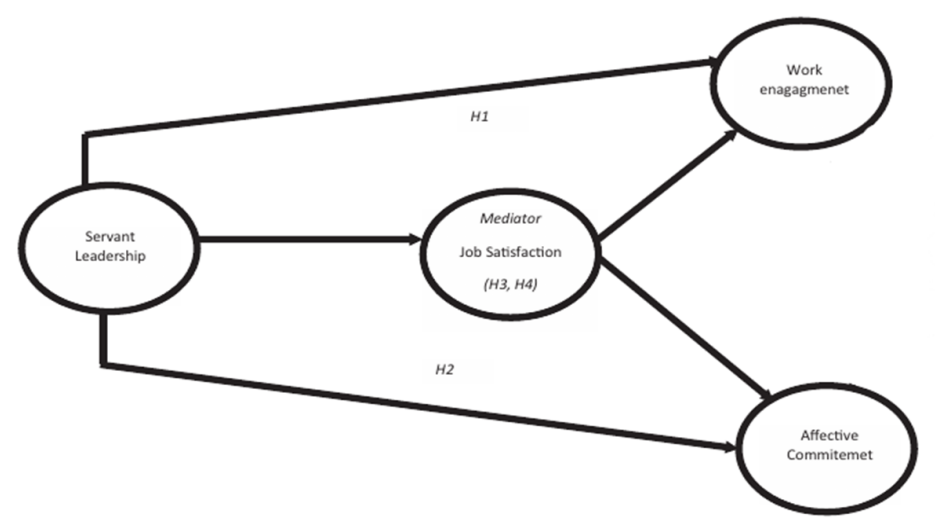

Fig. 1. Conceptual Framework

\subsection{Hypothesis}

H1: There is a positive effect of Servant leadership of work engagement on education staffs of private universities in West Jakarta

$\mathrm{H} 2$ : There is a positive effect of Servant leadership of Affective commitment on education staffs of Private Universities in West Jakarta

H3: Job satisfaction mediates positive effect between servant leadership and work engagement on education staffs of private universities in West Jakarta

H4: Job satisfaction mediates the positive effect between servant leadership and Affective commitment on Education staffs of private universities in West Jakarta.

\section{Research Methodology}

\subsection{Research Methods}

The research method uses quantitative methods by conducting case studies at private universities in West Jakarta which are ranked in the top 5 (five) best private universities in Jakarta according to the LLDIKTI version in 2020 and testing is done by hypothesis testing. The number of respondent in this study are 152. 


\subsection{Variable and Measurement}

In this study, the variables are Job Satisfaction, Work engagement, Servant leadership and Affective commitment. Servant Leadership as an independent variable, Job Satisfaction as an mediator variable, Work Engagement as an dependent variable and Affective Commitment as an dependent variable.

\subsection{Data Collection Methods}

The method of sampling used in this research is a method of non-probability sampling, where the method of non-probability sampling is the procedure of sample collection that is subjective in this case the elements- elements that exist in the population of his election is not specified. It because every element in the population does not have the same opportunities to determine the sample, with one method, namely sampling using the technique of purposive sampling is a sampling of research.

\subsection{Instrument Test}

Data collection was done by distributing questionnaires, sooth respondents in answering questions is an important thing in this study. Therefore, to avoid the occurrence of irregularities may occur on the measurement of conducted test instrument to be able to explain the purpose of the study and can also ensure consistent if statement is answered in a different time later in the day.

\subsection{Methods of Data Analysis}

In this study, the data analysis method used is Structural Equation Model (SEM) was used to assess the influence between each- each variable with the program PLS. Data analysis method used is adjusted with the aim of the research following:

a. To analyse the Training using descriptive statistics in the form of average

b. To analyse the Servant leadership using descriptive statistics in the form of average

c. To analyse the Job satisfaction using descriptive statistics in the shape average

d. To analyse the Affective commitment using statistics in the form of average.

\section{Results and Discussion}

\subsection{Respondent Profile}

Respondent Profile According to work period

\begin{tabular}{ccc}
\hline Work Period & Frequency & Percentage \\
\hline <1 Year & 11 & $7,2 \%$ \\
1-5 Years & 58 & $38,2 \%$ \\
6-10 Years & 51 & $33,6 \%$ \\
11-15 Years & 10 & $6,6 \%$ \\
$>$ 15 Years & 22 & $14,5 \%$ \\
Total & 152 & $100 \%$ \\
\hline
\end{tabular}


Majority of respondent have 1-5 years period of work with total 58 respondent. The reason is because a lot of respondent just start working on the university.

\begin{tabular}{ccc}
\multicolumn{3}{c}{ Respondent Profile According to Age } \\
\hline Age & Frequency & Percentage \\
\hline 20-29 Years old & 59 & $38,8 \%$ \\
30-39 Years old & 54 & $35,5 \%$ \\
40-49 Years old & 25 & $16,4 \%$ \\
$>$ 50 Years old & 14 & $9,2 \%$ \\
Total & 152 & $100 \%$ \\
\hline
\end{tabular}

Majority of respondent are 20-29 years old, the reason is in that age people are still on the productive stage and still have a lot of energy and motivation to working overtime

\begin{tabular}{ccc}
\multicolumn{3}{c}{ Respondent Profile According to Gender } \\
\hline Gender & Frequency & Percentage \\
\hline Male & 82 & $53,9 \%$ \\
Female & 70 & $46,1 \%$ \\
Total & 152 & $100 \%$ \\
\hline
\end{tabular}

Majority of respondent are Male with amount of 82 respondent. The reason is because they can do overtime work, and also could working on the past evening

\begin{tabular}{ccc}
\multicolumn{3}{c}{ Respondent Profile According to Latest Education } \\
\hline Education & Frequency & Percentage \\
\hline Senior High School & 47 & $30,9 \%$ \\
Diploma & 43 & $22,4 \%$ \\
Bachelor Degree & 59 & $38,8 \%$ \\
Master Degree & 12 & $7,9 \%$ \\
Total & 152 & $100 \%$ \\
\hline
\end{tabular}

Majority of respondent have the latest education of Bachelor Degree with amount of 59 respondent. That's because the respondent with bachelor degree tend to have better knowledge when it comes to problem solving and it's the minimum requirement for teaching or doing administrative work

\subsection{Descriptive Statistic}

Descriptive statistical analysis is used to provide an overview of a data. In this study, the descriptive statistics were the average value of the respondents' answers.

\begin{tabular}{clc}
\hline No & \multicolumn{1}{c}{ Work Engagement Statement Items } & Mean \\
\hline 1 & In my work I feel full of energy & 4.13 \\
2 & in my work i feel strong and excited & 4.30 \\
3 & I am enthusiastic about my work & 3.99 \\
4 & my work inspires me & 4.26 \\
5 & when i wake up in the morning i feel like to start working & 4.14 \\
6 & I feel happy when I work intensely & 4.14 \\
7 & I am proud of the work I do & 4.18 \\
8 & I get carried away when I work & 4.13 \\
& Total Mean & 4.15 \\
\hline
\end{tabular}


From the total mean of the work engagement variable of 4.15 , it can be concluded that employees agree about the existence of work engagement at the university. The largest average result is found in the statement item "in my work, I feel strong and enthusiastic" with an average value of 4.30 which means that employees agree that employees feel full of enthusiasm in completing their work. While the lowest average value is in the statement item "I am enthusiastic about my work" with an average value of 3.99 which means that employees quite agree that employees feel enthusiastic in carrying out their work.

\begin{tabular}{clc}
\hline No & Servant Leadership Statement Items & Mean \\
\hline 1 & My boss can tell if something is wrong with my work. & 4.03 \\
2 & My supervisor makes my career development a priority. & 4.23 \\
3 & My boss emphasized the importance of giving to others. & 4.22 \\
4 & My boss gives me the freedom to handle difficult situations in & 4.07 \\
& the way I think is best. \\
5 & My boss will not violate ethical principles for achieving success. & 4.13 \\
6 & My boss puts my best interests above his own. & 4.15 \\
\multicolumn{2}{c}{ Total Mean } & 4.14 \\
\hline
\end{tabular}

From the total mean on servant leadership variable of 4.14 , it can be concluded that employees agree about the implementation of servant leadership in the university work environment. The biggest average result is found in the statement item "My supervisor makes my career development a priority" with an average value of 4.23 , which means that employees agree that career development is a priority for leaders at the university. While the lowest average value in the statement item is "My supervisor can find out if there is something wrong related to my work" with an average value of 4.03 , which means employees agree that employees feel their leaders know when something is wrong. regarding employees at the university.

\begin{tabular}{clc}
\hline No & \multicolumn{1}{c}{ Job satisfaction statement items } & Mean \\
\hline 1 & I enjoy my work more than my free time. & 4.10 \\
2 & I feel that I am happier in my job. & 4.38 \\
3 & I find real pleasure in my work. & 4.05 \\
4 & Almost every day I am enthusiastic about my work. & 4.01 \\
5 & My work is interesting enough to keep me from getting bored. & 4.24 \\
6 & My job is like a hobby to me. & 4.23 \\
& & Total Mean \\
\hline
\end{tabular}

From the total mean variable Job satisfaction of 4.16, it can be concluded that employees are satisfied with the work they receive in a university environment. The largest average result is found in the statement item "I feel that I am happier in my job" with an average value of 4.38, which means that employees agree that they feel happy in carrying out the existing work. While the lowest average value is in the statement item "Almost every day I am enthusiastic about my work" with an average value of 4.01 which means that employees agree that employees are enthusiastic about their work almost every day.

\begin{tabular}{ccc}
\hline No & \multicolumn{1}{c}{ Affective Commitment Statement Items } & Mean \\
\hline 1 & I would love to spend the rest of my career at this institution. & 4.21 \\
2 & I feel that the problems at the company where I work are my problems too. & 4.16 \\
3 & I feel I will not be easy to be tied to other companies. & 4.13 \\
\hline
\end{tabular}




\begin{tabular}{clc}
\hline No & Affective Commitment Statement Items & Mean \\
\hline 4 & I feel like part of the family in this institution & 4.11 \\
5 & I have an emotional attachment to this institution & 4.14 \\
6 & This company has an important meaning in my personal & 4.22 \\
7 & I feel welcome in the company where I work & 4.16 \\
& Total Mean & 4.16 \\
\hline
\end{tabular}

From the total mean of the affective commitment variable of 4.16 , it can be concluded that employees agree with the commitments that exist in employees in the university environment. The largest average result is found in the statement item "This company has an important meaning in my personality" with an average value of 4.22 , which means that employees agree that the university where the employee works has an important meaning in the lives of employees. While the lowest average value is in the statement item "I feel like part of the family in this institution" with an average value of 4.11 , which means that employees agree that employees feel like part of the family in the university environment.

Validity test

\begin{tabular}{|c|c|c|}
\hline Work engagement variable & Results & Decision \\
\hline WE1 & 0.523 & Valid \\
\hline WE2 & 0.466 & Valid \\
\hline WE3 & 0.516 & Valid \\
\hline WE4 & 0.651 & Valid \\
\hline WE5 & 0.518 & Valid \\
\hline WE6 & 0.610 & Valid \\
\hline WE7 & 0.504 & Valid \\
\hline WE8 & 0.673 & Valid \\
\hline \multicolumn{3}{|c|}{ Servant leadership variables } \\
\hline Servant leadership variable & Results & Decision \\
\hline SL1 & 0.514 & Valid \\
\hline SL2 & 0.599 & Valid \\
\hline SL3 & 0.629 & Valid \\
\hline SL4 & 0.644 & Valid \\
\hline SL5 & 0.536 & Valid \\
\hline SL6 & 0.641 & Valid \\
\hline \multicolumn{3}{|c|}{ Job satisfaction variable } \\
\hline Job satisfaction variable & Results & Decision \\
\hline JS1 & 0.601 & Valid \\
\hline JS2 & 0.526 & Valid \\
\hline JS3 & 0.602 & Valid \\
\hline JS4 & 0.493 & Valid \\
\hline JS5 & 0.489 & Valid \\
\hline JS6 & 0.621 & Valid \\
\hline \multicolumn{3}{|c|}{ Affective commitment } \\
\hline Job satisfaction variable & Results & Decision \\
\hline $\mathrm{AC} 1$ & 0.554 & Valid \\
\hline $\mathrm{AC} 2$ & 0.483 & Valid \\
\hline $\mathrm{AC} 3$ & 0.696 & Valid \\
\hline $\mathrm{AC} 4$ & 0.603 & Valid \\
\hline
\end{tabular}




\begin{tabular}{ccc}
\hline Job satisfaction variable & Results & Decision \\
\hline AC5 & 0.669 & Valid \\
AC6 & 0.594 & Valid \\
AC7 & 0.574 & Valid \\
\hline
\end{tabular}

From the results of the validity test above, it can be seen that the value of loading factor for all variable items is greater than the lower limit of the validity test that can be declared valid or equal to (0.45). Thus, all statement items in each variable can be declared valid and can represent the variables being studied.

\begin{tabular}{lcc}
\multicolumn{3}{c}{ Reliability Test } \\
\hline \multicolumn{1}{c}{ Variable Name } & Cronchbatch Alpha & Decision \\
\hline Work engagement & 0.650 & Reliable \\
Servant leadership & 0.631 & Reliable \\
Job satisfaction & 0.621 & Reliable \\
Affective commitment & 0.689 & Reliable \\
\hline
\end{tabular}

From the results of the cronchbatch alpha from all four variables, it can be seen that the number exceeds 0.6 or the minimum limit of the reliability test. Therefore, the four variables can be declared reliable or can be continued for research.

\subsection{Hypothesis Testing Results}

\section{Hypothesis 1}

Hypothesis 1 examines whether Servant leadership has an effect on work engagement. The null hypothesis (Ho) and the alternative hypothesis (Ha) are as follows:

Ho: Servant leadership does not have a positive effect on work engagement

$\mathrm{H} 1$ : Servant leadership has a positive influence on work engagement

Table 4.1 Hypothesis Testing Results 1

\begin{tabular}{cccc}
\hline & \multicolumn{4}{c}{ Estimate } & p-value (1 Tails) & Decision \\
\hline $\begin{array}{c}\text { H1: Servant leadership has a positive } \\
\text { effect on work engagement }\end{array}$ & 0.118 & 0.087 & Ho rejected \\
\hline \multicolumn{3}{c}{ Source: SPSS Version 22 pengolahan processing results } \\
\hline \multicolumn{4}{c}{. }
\end{tabular}

Based on the results of testing hypothesis 1 in table 4.8 , it is known that the obtained estimated value is 0.483 and the p-value is $0.000<0.1$ (error rate $10 \%$ ), then Ho is rejected and Ha is accepted, which means that hypothesis 1 is accepted, so it can be concluded that there is a significant effect ofServant leadership to work engagement. This shows that employees feel the application ofServant leadership what the company does affects the level of work engagement that exist in employees.

\section{Hypothesis 2}

Hypothesis 2 examines whether Servant leadership has an effect on Affective commitment. The null hypothesis (Ho) and the alternative hypothesis (Ha) are as follows:

Ho: Servant leadership does not have a positive effect on Affective commitment

$\mathrm{H} 2$ : Servant leadership has a positive effect on Affective commitment 
Table 4.2 Hypothesis Testing Results 2

\begin{tabular}{lccc}
\hline & Estimate & $\boldsymbol{p}$-value (1 Tails) & Decision \\
\hline $\begin{array}{l}\text { H2: Servant leadership has a positive } \\
\text { effect on Affective commitment }\end{array}$ & 0.775 & 0.000 & Ho rejected \\
\hline \multicolumn{2}{c}{ Source: SPSS Version 22 } & pengolahan processing results
\end{tabular}

Based on the results of testing hypothesis 2 in table 4.8 , it is known that the estimated value obtained is 0.483 and the p-value is $0.000<0.1$ (error rate10\%), then Ho is rejected and $\mathrm{Ha}$ is accepted, which means that hypothesis 2 is accepted, so it can be concluded that there is a significant effect ofServant leadership to Affective commitment. This shows that employees feel the application ofServant leadership what the company does affects the level of Affective commitment that exist in employees.

\section{Hypothesis 3}

Hypothesis 3 examines whether Servant leadership has an influence on work engagement mediated by job satisfaction. The null hypothesis (Ho) and the alternative hypothesis (Ha) are as follows:

Ho: Servant leadership does not have a positive effect on work engagement mediated by job satisfaction

H3: Servant leadership has a positive influence on work engagement mediated by job satisfaction

Table 4.3 Hypothesis Testing Results 3

\begin{tabular}{lccc}
\hline & Estimate & p-value (1 Tails) & Decision \\
\hline $\begin{array}{l}\text { H3: Servant leadership has a positive effect on } \\
\text { work engagement mediated by job satisfaction }\end{array}$ & $\mathbf{0 . 2 6 3}$ & 0.003 & Ho rejected \\
\hline \multicolumn{4}{c}{ Source: SPSS Version 22 pengolahan processing results }
\end{tabular}

Based on the results of testing hypothesis 3 in table 4.8, it is known that the obtained estimated value is 0.483 and the p-value is $0.000<0.10$ (error rate $10 \%$ ), then Ho is rejected and $\mathrm{Ha}$ is accepted, which means hypothesis 3 is accepted, so it can be concluded that there is a significant effect ofServant leadership to work engagement mediated by the Job satisfaction variable. This shows that the implementation of Servant leadership in the company will increase the job satisfaction felt by employees which in turn can increase the work engagement that exists in employees.

\section{Hypothesis 4}

Hypothesis 4 examines whether Servant leadership has an influence on Affective commitment mediated by job satisfaction. The null hypothesis (Ho) and the alternative hypothesis (Ha) are as follows:

Ho: Servant leadership does not have a positive effect on Affective commitment mediated by Job satisfaction

H4: Servant leadership has a positive influence on Affective commitment mediated by Job satisfaction

Table 4.4 Results of Hypothesis Testing 4

\begin{tabular}{|c|c|c|c|}
\hline & Estimate & p-value (1 Tails) & Decision \\
\hline $\begin{array}{l}\text { H4: Servant leadership has a positive effect on } \\
\text { Affective commitment mediated by Job satisfaction }\end{array}$ & 0.509 & 0.000 & Ho rejected \\
\hline
\end{tabular}


Based on the results of testing hypothesis 4 in table 4.8 , it is known that the obtained estimated value is 0.483 and the p-value is $0.000<0.10$ (error rate $10 \%$ ), then Ho is rejected and $\mathrm{Ha}$ is accepted, which means that hypothesis 4 is accepted, so it can be concluded that there is a significant effect of Servant leadership to work engagement mediated by the Job satisfaction variable. This shows that the implementation of Servant leadership in the company will increase the perceived job satisfaction of employees which in turn can increase employee satisfactionAffective commitment that is in the employee.

\section{Conclusion}

\subsection{Conclusion}

1. From the results of the work engagement analysis, it can be concluded that education personnel who work at private universities in the West Jakarta area have felt an attachment to their work. In addition, the employee is also inspired by the work he does.

2. From the results of the servant leadership analysis, it can be concluded that private universities in the West Jakarta area have implemented leadership that serves employees at their universities. In addition, leaders at universities in the West Jakarta area also prioritize the career development of every education staff there.

3. From the results of the job satisfaction analysis, it can be concluded that education personnel who work at private universities in the West Jakarta area have high job satisfaction. In addition, existing employees also think that the work they do does not make employees feel bored quickly

4. From the results of the affective commitment analysis, it can be concluded that the education staff who work at private universities in the West Jakarta area have a fairly high commitment to their work. Employees also feel that the university where the employee works has an important meaning in his life.

5. From the results of the first hypothesis, it can be concluded that Servant leadership has a positive effect on work engagement with an estimate of 0.118 . This supports previous research, so it is believed that there is a significant positive effect of Servant leadership on work engagement. The application of leadership that prioritizes employee input can increase the work engagement that exists within employees

6. From the results of the second hypothesis, it can be concluded that Servant leadership has a positive effect on Affective commitment with an estimate of 0.775. This supports previous research, so it is believed that there is a significant positive effect of Servant leadership on Affective commitment. The application of Servant leadership in a company can increase the commitment possessed by employees

7. The calculation results on the third hypothesis can be concluded that job satisfaction mediates the positive influence of Servant leadership on work engagement with an estimate of 0.263 . Servant leadership applied in a company can trigger an increase in job satisfaction for employees. The increase in job satisfaction also increases the work engagement that exists in employees, because the employees feel satisfied with their work, the more enthusiastic the employee is in completing his work.

8. The results of the calculations on the fourth hypothesis can be concluded that job satisfaction mediates the positive influence of Servant leadership on Affective 
commitment with an estimate of 0.509. This shows that the implementation of Servant leadership will increase the existing job satisfaction of employees. And with feelings of pleasure in employees towards their work, commitment in employees to the company will also increase.

\subsection{Implication}

1. Overall, the education staff who work at private universities in the West Jakarta area have felt a fairly high level of work engagement in their workplace. Things that can be done to increase work engagement include making employees at universities in the West Jakarta area enthusiastic about their work.

2. Overall, universities in the West Jakarta area have implemented good servant leadership. Improvements made can only improve communication between university leaders and their employees.

3. Overall, the education staff who work at private universities in the West Jakarta area have felt quite high job satisfaction. Improvements that can be made are in the form of giving employees free time in accordance with their work

4. Overall, the education staff who work at private universities in the West Jakarta area have a good level of affective commitment. Improvements that can be made are by increasing the emotional bond between employees so that they feel like brothers.

\subsection{Suggestions for Further Research}

1. Research can use other variables that can affect work engagement and affective commitment to employees

2. Research can be conducted at private universities in Jakarta, not only limited to private universities in West Jakarta

\section{References}

[1] M. R. Ayers, “Agapao in servant leadership," Servent Leadersh. Roundtable, no. May, p. 20, 2008.

[2] W. B. Schaufeli and A. B. Bakker, "Job demands, job resources, and their relationship with burnout and engagement: A multi-sample study," J. Organ. Behav., vol. 25, no. 3, pp. 293-315, 2004, doi: 10.1002/job.248.

[3] D. van Dierendonck and I. Nuijten, "The Servant Leadership Survey: Development and Validation of a Multidimensional Measure," J. Bus. Psychol., vol. 26, no. 3, pp. 249267, 2011, doi: 10.1007/s10869-010-9194-1.

[4] J. Schaubroeck, S. S. K. Lam, and A. C. Peng, "Cognition-Based and Affect-Based Trust as Mediators of Leader Behavior Influences on Team Performance," J. Appl. Psychol., vol. 96, no. 4, pp. 863-871, 2011, doi: 10.1037/a0022625.

[5] D. Carter and T. Baghurst, "The Influence of Servant Leadership on Restaurant Employee Engagement," J. Bus. Ethics, vol. 124, no. 3, pp. 453-464, 2014, doi: 10.1007/s10551-013-1882-0.

[6] M. Coetzer, M. Bussin, and M. Geldenhuys, "The Functions of a Servant Leader," Adm. Sci., vol. 7, no. 1, p. 5, 2017, doi: 10.3390/admsci7010005.

[7] T. Reio and R. Ghosh, "Antecedents and Outcomes of Workplace Incivility," Comput. 
Complex., vol. 2, no. 1, pp. 1-9, 2009, doi: 10.1002/hrdq.

[8] P. Kaur, "Mediator Analysis of Job Satisfaction: Relationship between Servant Leadership and Employee Engagement," Metamorph. A J. Manag. Res., vol. 17, no. 2, pp. 76-85, 2018, doi: 10.1177/0972622518804025.

[9] Q. Ling, F. Liu, and X. Wu, "Servant Versus Authentic Leadership: Assessing Effectiveness in China's Hospitality Industry," Cornell Hosp. Q., vol. 58, no. 1, pp. 53-68, 2017, doi: 10.1177/1938965516641515.

[10] G. P. M. Dick, "The influence of managerial and job variables on organizational commitment in the police," Public Adm., vol. 89, no. 2, pp. 557-576, 2011, doi: 10.1111/j.1467-9299.2010.01874.x.

[11] T. A. Jackson, J. P. Meyer, and X. H. Wang, "Leadership, commitment, and culture: A meta-analysis,” J. Leadersh. Organ. Stud., vol. 20, no. 1, pp. 84-106, 2013, doi: $10.1177 / 1548051812466919$.

[12] A. Gregory Stone, R. F. Russell, and K. Patterson, "Transformational versus servant leadership: A difference in leader focus," Leadersh. Organ. Dev. J., vol. 25, no. 4, pp. 349-361, 2004, doi: 10.1108/01437730410538671.

[13] G. Yukl and R. Mahsud, "Why flexible and adaptive leadership is essential," Consult. Psychol. J., vol. 62, no. 2, pp. 81-93, 2010, doi: 10.1037/a0019835.

[14] M. J. Neubert, E. M. Hunter, and R. C. Tolentino, "A servant leader and their stakeholders: When does organizational structure enhance a leader's influence?," Leadersh. Q., vol. 27, no. 6, pp. 896-910, 2016, doi: 10.1016/j.leaqua.2016.05.005.

[15] O. E. Amah, "Determining the antecedents and outcomes of servant leadership," $J$. Gen. Manag., vol. 43, no. 3, pp. 126-138, 2018, doi: 10.1177/0306307017749634.

[16] R. Blizzard, "Engagement vs. Satisfaction Among Hospital Teams.," Gall. Poll Tuesday Brief., pp. 1-3, 2004.

[17] A. M. Saks, "Antecedents and consequences of employee engagement," J. Manag. Psychol., vol. 21, no. 7, pp. 600-619, 2006, doi: 10.1108/02683940610690169.

[18] J. P. Meyer, D. J. Stanley, L. Herscovitch, and L. Topolnytsky, "Affective, continuance, and normative commitment to the organization: A meta-analysis of antecedents, correlates, and consequences," J. Vocat. Behav., vol. 61, no. 1, pp. 20-52, 2002, doi: 10.1006/jvbe.2001.1842.

[19] K. M. Dirani and K. P. Kuchinke, "Job satisfaction and organizational commitment: Validating the arabic satisfaction and commitment questionnaire (ASCQ), testing the correlations, and investigating the effects of demographic variables in the lebanese banking sector," Int. J. Hum. Resour. Manag., vol. 22, no. 5, pp. 1180-1202, 2011, doi: 10.1080/09585192.2011.556801.

[20] W. B. Schaufeli, "Work Engagement: What do we know?," Int. OHP Work., no. December, pp. 1-60, 2011.

[21] W. B. Schaufeli, "What is engagement?," Empl. Engagem. Theory Pract., pp. 15-35, 2013, doi: 10.4324/9780203076965.

[22] T. W. Taris, J. F. Ybema, and I. van Beek, "Burnout and engagement: Identical twins or just close relatives?,” Burn. Res., vol. 5, no. May, pp. 3-11, 2017, doi: 10.1016/j.burn.2017.05.002.

[23] S. Sonnentag, "A task-level perspective on work engagement: A new approach that helps to differentiate the concepts of engagement and burnout," Burn. Res., vol. 5, no. April, pp. 12-20, 2017, doi: 10.1016/j.burn.2017.04.001.

[24] C. S. Hayward et al., "Impact of left ventricular assist device speed adjustment on exercise tolerance and markers of wall stress," Int. J. Artif. Organs, vol. 38, no. 9, pp. 
501-507, 2015, doi: 10.5301/ijao.5000431.

[25] M. Geldenhuys, K. Laba, and C. M. Venter, "Meaningful work, work engagement and organisational commitment," SA J. Ind. Psychol., vol. 40, no. 1, pp. 1-10, 2014, doi: 10.4102/sajip.v40i1.1098.

[26] J. D. Parent and K. J. Lovelace, "The Impact of Employee Engagement and a Positive Organizational Culture on an Individual 's Ability to Adapt to Organization Change," East. Acad. Manag. Proc. Organ. Behav. Theory Track, pp. 1-20, 2015.

[27] N. P. Vokic, "The triad of job satisfaction, work engagement and employee loyalty The interplay among the concepts," EFZG Work. Pap. Ser., vol. 15, no. 07, pp. 1-13, 2015.

[28] E. W. Kartika, T. S. Kaihatu, M. Adiwijaya, and A. Nugroho, "Perceived Supervisor Support (PSS), Affective Commitment, and Organizational Citizenship Behavior (OCB): Study in Indonesian Context," Sustain. Entrep. Organ. Pap. Present. ICOEN 3rd Int. Conf. Entrep. Surayabay Univ. Ciputra, pp. 180-192, 2017.

[29] D. Van Dierendonck, D. Stam, P. Boersma, N. de Windt, and J. Alkema, "Same difference? Exploring the differential mechanisms linking servant leadership and transformational leadership to follower outcomes," Leadersh. Q., vol. 25, no. 3, pp. 544-562, 2014, doi: 10.1016/j.leaqua.2013.11.014.

[30] A. Alvinius, E. Johansson, and G. Larsson, "Job satisfaction as a form of organizational commitment at the military strategic level: A grounded theory study," Int. J. Organ. Anal., vol. 25, no. 2, pp. 312-326, 2017, doi: 10.1108/IJOA-10-2015-0919.

[31] G. Akehurst, J. M. Comeche, and M. A. Galindo, "Job satisfaction and commitment in the entrepreneurial SME," Small Bus. Econ., vol. 32, no. 3, pp. 277-289, 2009, doi: 10.1007/s11187-008-9116-z.

[32] J. P. Meyer and N. J. Allen, "TCM Employee Commitment Survey Academic Users Guide 2004," London, Ontario, Canada Univ. West. Ontario, Dep. Psychol., vol. University, p. 16, 2004. 